\title{
Between Sinification and Internationalization: Chinese Political Science in the Post-Reform Era
}

\author{
Jon R. Taylor ${ }^{1}$
}

Received: 15 January 2016/ Accepted: 22 February 2016/Published online: 22 April 2016

(C) Fudan University and Springer Science+Business Media Singapore 2016

\begin{abstract}
The story of Chinese political science since Reform and Opening-up is one that parallels China itself: rapid and remarkable development. This article poses a series of questions regarding the current standing of Chinese political science, its relevance and future as a discipline within China, its contributions to Chinese academia, policy making, and society, and it place within a global discipline.
\end{abstract}

Keywords Chinese political science $\cdot$ Indigenization $\cdot$ Applied policy $\cdot$ Relevance

\section{Introduction}

"Chinese political science is developing its own plurality of methodological approaches to the study of politics."-Deng (2008).

What exactly is Chinese political science in the 21 st century? How does it diverge from its Western counterparts? How does it parallel its Western counterparts? How does it contribute to the overall discipline's body of knowledge? Can Chinese political science contribute to China's understanding of the nuances of its political system in a way that is both meaningful and practically relevant? What does Chinese political science tell us about important real-world problems and issues? And to what extent does and can political analysis with "Chinese characteristics" contribute to policy solutions?

Before we explore these questions and present-day political science in China, it is appropriate to begin with an overview of the discipline's past. Specifically, how academic Chinese political science arose in the late Qing Dynasty, its early

Jon R. Taylor

taylorj@sthom.edu

1 Department of Political Science, University of St. Thomas, Houston, TX 77006-4626, USA 
expansion during the Republican period, its travails during the Anti-Japanese War, the impact on the discipline after the founding of New China in 1949, its abolition between 1952 and 1978, its restoration as an academic field after Reform and Opening-Up in 1979, and its present-day rise to prominence.

\section{Chinese Political Science: A History}

$\mathrm{Yu}$ (2009) has succinctly noted that there is a "distinction between political science in the narrow sense and political science in the broad sense." In this respect, the practical performance of Chinese political science in a broad, historical sense is the practice of politics - one that parallels that found in the west and elsewhere: statecraft, the management of the state, and the promulgation and enforcement of the law. In this respect, political science is one of the most enduring and transcending of human institutions. In the narrow scholarly sense, Chinese political science can trace its roots to the late 19th century and early 20 th century.

The history of academic political science in China is the result of the ideological struggles, societal upheavals, and changes in the political system that are particular to China both before and after Liberation in 1949 (Zhao 1984). Chinese political science can be divided into four historical periods: antiquity to the 1911 revolution era, pre-liberation vibrancy, abolition in the 1950s, and restoration after the cultural revolution during Reform and Opening-Up (Zhao 1984; Wang 2011; Taylor 2011; He 2011).

Like its Western counterpart, Chinese political science can claim to be one of the oldest of academic disciplines. Both share a common pre-modern history and tradition of offering both advice and deference to authority. In the case of China, this tradition would be put to the test as a result of the interaction and humiliations precipitated by the West during the late Qing Dynasty. These degradations would spur the rise of a self-strengthening movement among academics, intellectuals, and reform-minded officials that aimed to both modernize and reform China by importing Western methods, ideas, and ideology, including public administration and the scientific study of politics (Palm 2012).

A concern about the administration of government and the stability of the political system would lead to the creation of the Political Studies Department at Metropolitan University (now Peking University) in 1898 and the teaching of the first collegiate courses in political science by 1903 (Wang 2011; Zhao 1984; Sun 2005). The tumult of the Yuan Shikai era and the end of the republican government would again underscore the need to examine Western concepts of political institutions and constitutional development (Jenne 2015).

In the pre-liberation era, Chinese political science was marked by strong growth and popularity. The discipline was second in popularity only to law among the university students during this time period (Sun 2005; Liu and Yang 1999). Some, such as Wang (2011) and Bai (2014) suggest that the reason for political science's popularity was that after the abolition of the imperial examination system in 1905 , many students and scholars alike regarded the study of political science as a short cut to a career in the public service-ironically, quite similar to today in this respect. 
Emblematic of the discipline's popularity was the operation of approximately 45 university-based political science departments on the eve of Liberation in 1948. However, while the discipline was growing - an offshoot of this growth was the establishment of the Chinese Political Science Association in 1932-the discipline had little interest within China for a Chinese perspective, let alone an interest in indigenizing political science. Rather, those teaching and conducting research in Chinese political science departments were heavily influenced by Western, particularly American, scholars and ideas, and they tended to emphasize comparative politics, normative theory, and public administration (Wangling 2007).

Political science's pre-liberation success came at a high price when the People's Republic was established in 1949. Many scholars who were members of the Chinese Political Science Association fled the mainland, leaving the discipline with an estimated one hundred members or less in the entire country (Zhao 1984). The discipline's bourgeois Western affiliations and affectations, as well as its comparative and normative outlook, marked it as suspect and untrustworthy in the eyes of the Communist Party of China (CPC).

While political science had long been criticized by the CPC both before and after liberation for its western biases and tendencies, the view that the discipline was untrustworthy and therefore bourgeois would lead to its abolition as an independent scholarly discipline by 1952 (Zhao 1984; Wang 2011). Where it still remained, it was merged into departments of economics, law, international politics, or Marxism (Qin 2011; Chow 1991; Brugger 1986). After 1952, when political science was taught, it would be highly constrained. Specifically, political science courses after 1960 would focus primarily on Marxism-Leninism, Mao Zedong Thought, and/or international politics (Wang 2011). It would remain this way until Reform and Opening-Up in 1978.

Reform and Opening-Up served as the catalyst to rebuild Chinese political science. The restoration of political science as an independent academic discipline began modestly in May of 1977, when the Chinese Academy of Social Sciences (CASS) was established on the basis of the Social Science Division of the Chinese Academy of Sciences and created an institutional setting for the revival of political science as well as other social sciences (Fu 1991). In 1978, then-CPC Chairman Hua Guofeng advocated a plan for research topics in political science (Zhao 1984). This would be followed in 1979 in a speech made by Deng Xiaoping in which he conceded that, "For many years we have neglected the study of political science, jurisprudence, sociology, and world politics... For many years we don't even have statistical figures" (Deng 1983).

While the restoration of political science in China was not an easy endeavorsome suggested that political science had little practical utility in assisting in the CPC's reforming efforts - it did help to be in the right place at the right time after Deng's speech. Within a year of the speech, both the Chinese Association of Political Science (CPSA) was created and Social Sciences in China (中国社会科学) was founded (Brugger 1986; Wang 2011; Noakes 2014). By 1987, the CPC's 13th Party Congress formally acknowledged that political science could make an important contribution to China's political modernization and reform agenda (Petracca 1990). 
Since the 1980s, Chinese political science has experienced what might best be described as an academic renaissance. The discipline was not only restored, but lifted to a level of prominence through CASS. Its popularity as a discipline rose rapidly, with present-day political science departments numbering in the hundreds and offering majors at both the undergraduate and graduate levels (Wang 2011). Additionally, Chinese political scientists are making significant contributions to China's on-going dialogue regarding economic, political, social, and legal reform. As some have noted, it is a political science that can not only advance China's national interests, but can also provide an alternative approach to the study of politics and the research agenda of the discipline. In short, it can offer a political science with "Chinese Characteristics" (Taylor 2009, 2011; Deng 2008; He 2011).

\title{
3 How Does Chinese Political Science Both Diverge from and Parallel Its Western Counterparts?
}

\author{
"Make the Past Serve the Present and Foreign Things Serve China."-Mao \\ Zedong (Brady 2003).
}

If one can understand modern American political science through its roots and history, it should also hold true for Chinese political science. Contemporary American political science developed from the study of American history and its political institutions. Many of the scholarly assumptions of American political science flow from that background (Lieberthal 2010). The history of American political science is a combination of an emphasis on science, the rise of the modern American research university system, and an understanding of how both people and the governments that serve them interact and behave (Taylor 2009). The same can be said for the activity of political science in other regions of the world.

If we accept the axiom that the study of history and political institutions shape both the development and paradigms of contemporary political science, then does it not stand to reason that Chinese political science should be shaped by China's history and political institutions? Given the wealth of history that flows from a civilizational state as well as from the current system of socialism with Chinese characteristics, it should be assumed that political science in China would naturally pursue an indigenized path (Wang 2013).

Song Yingfa (2015) posits that during the past 30 years, Chinese political science research has experienced great development through the introduction and translation of Western political science research results, especially those of contemporary American political science. More importantly, Song notes that the attention to and the study of the political practices in China was and is inadequate on the part of the discipline.

Wang (2011) also notes that political science in China has experienced two stages of development, the first of which was the "uncritical learning" stage and the "gullible emulating" stage. Chinese political science has now entered into a new stage: conscious indigenization. While some may seem this as a negative, indigenizing Chinese political science-in scholarly research, applied policy 
analysis, and academic curricula—will have an overall positive effect by providing a platform by which the discipline can accurately describe and interpret, and, yes, even influence Chinese politics (Wu 2013; Song 2015).

The issue of indigenization both pushes and pulls Chinese political science. This push-pull has the effect of both contending with and complimenting the other pushpull tendency of the discipline both in China and the United States: internationalization. Almost 15 years ago, David Zweig observed that Reform and Opening-Up would lead to the internationalization of Chinese higher education as scholars and universities alike sough transnational channels and linkages (Zweig 2002). Internationalizing political science provides the means to internationalize both scholarly ideas and shared research values (Song 2015).

While there has been a strong trend toward internationalization in political science, the preponderance of American political science and its dominant role globally within the discipline has ironically set the stage for further indigenization by encouraging the rise of national and nation-based political science (Daalder 1984).

What exactly, then, is Chinese political science? Is it an amalgam of disparate disciplinary threads? The answer is, of course, yes. We know that it is a discipline that both greatly differs from and parallels its American counterpart. Its contentious early history, its abolition for over two decades, and its restoration are experiences that are alien to that of American political science.

However, like American political science, Chinese political science can be divided into subfields that reflect both the historical scope and scholarly context of the discipline within China (CASS Institute of Political Science 2015):

- Marxism and marxist theory.

- Normative/non-marxist political theory.

- Political systems and institutions.

- Public administration.

- Political culture.

- Comparative politics.

These subfields reflect not only the localized Chinese experience, but also the push-pull of internationalization, similar to what is found within American political science. What distinguishes political science as a social science discipline is its emphasis on government and power. However, the study of government and power is obviously not confined to just political science. It is within the context of crossdisciplinary permeation that may provide a relatively unique venue for Chinese political science.

Liang Ying (2012) speculates that the discipline can be both indigenized and cross-disciplinary within China. Specifically, Liang suggests that Chinese political science may best serve both disciplinary and national interests by focusing on seven cross-disciplinary approaches: political anthropology, political psychology, ethnic politics, political communication, political geography, political demography and bio-politics. Liang makes a compelling case for new approaches to both enhancing and expanding Chinese political science. A cross-disciplinary Chinese political 
science underscores the new emphasis on the part of China to develop intellectually energetic, cross-disciplinarily vibrant, and politically relevant indigenous think tanks. It is the issue of relevance that, like its Western counterparts, Chinese political science faces in the decade ahead.

\section{Should Chinese Political Science be Relevant?}

To answer this question requires that we compare Chinese political science, political studies, policy studies, and public administration against its American and counterpart. In this respect, Chinese political science must find a way to overcome a long-held criticism of the discipline regarding its utility by demonstrating its relevance as a discipline, one that can move beyond the theoretical and the academic to the practical and applied.

The question that really needs to be asked is this: Should Chinese political science follow, lead, or get the hell out of the way? This is neither as flippant nor as smarmy as it may appear at first glance. As a nation that has reasserted itself into the world since Reform and Opening-Up, it seems limiting to suggest that Chinese political science should pursue paths similarly tread by confreres in the United States and Europe.

As the history of American political science-and my subfield of public administration both demonstrate-vibrant scholarly work, new areas of research, and substantive practical solutions for national and sub-national policy needs, arose parallel to the rise of the United States as a world power during the first half of the 20th century. While correlation does not necessarily imply causation, nevertheless it can be posited that the rising dominance of American political science during the 20th century is owed, in part, to the preeminence of the United States on the world stage. Concomitantly, could it not be argued that as China rises on the world stage, should its political science not similarly rise to meet the growing policy, development, and administrative needs of the nation?

From politicians to opinion makers in the United States, this question is often asked: Why is the public persona of American political science that of an aloof, unwelcoming discipline, frustratingly unapproachable to the average citizen; maddeningly ineffectual with both politicians and policy makers alike (Trent 2011)? American political science seems intent on marginalizing itself by refusing to make its research understandable, let alone useful, to those whom we supposedly desire to serve: citizens and their governments at all levels. As Joseph Nye once observed: "There are parts of the academy which, in the effort to be scientific, feel we should stay away from policy because it interferes with the science" (Cohen 2009).

During the past quarter century, American political science has been roundly criticized for its inability to remain relevant to the "real world" and for its failure to significantly influence the scope of discussion in both politics and public policymaking. Like it or not, the discipline faces a serious a problem: Does the practice of political science live up to its full potential as a scholarly discipline that should enrich the discourse, broaden the understanding, and model the behavior 
necessary to build civic engagement in a rapidly changing world where population shifts and related issues regarding race, ethnicity, immigration, and equal opportunity structure some of the most significant conflicts affecting politics and policymaking? The answer, too often, is a resounding no.

The issue of relevance in American political science is a cautionary tale for Chinese political science. Should Chinese political science emulate the same path tread by their American counterparts? Probably not, based on the perception that the discipline is relatively marginalized in the United States.

Peters et al. (2010) suggest that the relevance of Western-particularly American and British-political science is rather dismal, given its inability to offer workable solutions to policy problems. Others, such as Rogowski (2013) argue that political science produces highly policy-relevant research, but politicians ignore it in favor of their own (or their supporters') biases. Wood (2014) suggests that there are two ways to bridge the relevance gap, namely through greater efforts by researchers to increase the accessibility and interactivity of their research.

Why is this pertinent to Chinese political science? Because the current emphasis by the CPC on developing policy think tanks is a positive development for scholars within the discipline and offers the possibility that Chinese political science can attain the utilitarian relevance that it has long sought-a relevance that continues to create contention within American political science. While political scientists in China have long contributed to careful and considered political studies, Marxist theory, and international relations, the prospect of offering tangible, applied policy solutions for China's myriad societal issues and problems is a quite promising development.

\section{Conclusion}

What exactly is Chinese Political Science in the 21 st century? Is it an imitation of Western, particularly American, political science due to its history and methodologies? Or is it something else, a discipline that has its own characteristics that are both localized and unique to China?

Perhaps Professor Yan Xuetong, Director of the Tsinghua University's Institute of Modern International Relations, may have put it best when he recently noted, "there is no general Chinese school but rather small enclaves within political science" (Chinese Social Sciences Today 2015). Conversely, Professor Zhang Shengjun Deputy Dean of the Institute of Political Science and International Studies at Beijing Normal University, may have provided an answer when he suggested that there is the possibility of a Chinese path (Tsinghua School of Social Sciences 2015). So which is it? As an American and obvious outsider, I would suggest that it is both.

Like American political science, many obstacles exist within China's political science, particularly its ability to influence policymakers, promote modern governance, and effectively communicate with their international counterparts. Like its international counterparts, it continues to ponder the role that both normativism and positivism play within the discipline. However, Chinese political science suffers from one unique malady: language. A robust body of scholarly 
political science research resides within China, unfortunately confined by language barriers, translation issues, and gated journal article accessibility. For those nonChinese fortunate enough to access sites like CNKI, there is a tremendous amount of excellent scholarly work by Chinese political scientists.

That said, for a discipline that was in a state of suspended animation from 1952 to 1978, it has accomplished much during the last 37 years. The sinification of political science suggests a discipline that has developed, grown, and matured during the past two decades. The key to China finding a niche within the global discipline of political science may be in the area of applied research, one that considers not only political science, but, instead, takes a cross-disciplinary approach with China's other social sciences. Given the current level of government interest and financial support, Chinese political science has an opportunity that American political science once had some 30-40 years ago (and squandered): to provide consistent and methodologically sound applied policy research on specific political, social, and economic needs which have serious societal consequences, with the idea that assessing and understanding these problems can guide effective government policy formation and action.

\section{References}

Bai, Ying. 2014. Farewell to confucianism: The modernizing effect of dismantling China's imperial examination system. Working paper, Hong Kong University of Science and Technology, June 2014.

Brady, Anne-Marie. 2003. Making the foreign Serve China: Managing foreigners in the People's Republic. Lanham: Rowman and Littlefield.

Brugger, Bill. 1986. The revival of political science in China: A review of the journal Zhengzhixue Yanjiu. The Australian Journal of Chinese Affairs 15(January): 125-140.

Chinese Academy for Social Sciences (CASS) Institute of Political Science. 2015. Introduction to political science. http://chinaps.cass.cn/intro.htm.

Chinese Social Sciences Today. 2015. Scholars discuss 'Chinese school' of political science. http://www. csstoday.com/Item/1540.aspx.

Chow, King W. 1991. Public administration as an academic discipline in China. In Handbook of comparative and development administration, ed. Ali Farazmand. New York: Marcel Dekker.

Cohen, Patricia. 2009. Field study: Just how relevant is political science? New York Times, October 20, 2009, p C1.

Daalder, Hans. 1984. The internationalisation of political science: Promises and problems. In Comparative government and politics: Essays in honour of S.E. Finer, ed. Dennis A. Kavanagh, and Gilian Peele. London: Heinemann.

Deng, Xiaoping. 1983. Upholding the four cardinal principles. In: Selected works of Deng Xiaoping, vol 1, 2nd edn. Beijing: People's Press.

Deng, Zhenglai. 2008. The development of China's social sciences: Retrospect and prospect (1978-2008). Unpublished keynote speech from "China after the 17th party congress" Conference, October 11, 2008, Missouri State University, Maryville, Missouri.

Fu, Zhengyuan. 1991. The sociology of political science in the People's Republic of China. In The development of political science: A comparative survey, ed. David Easton, G.John Gunnell, and Luigi Graziano. New York: Routledge.

He, Baogang. 2011. The Dilemmas of China's Political Science in the Context of the Rise of China. Journal of Chinese Political Science 16(June): 257-277.

Jenne, Jeremiah. 2015. The perils of advising the empire: Yuan Shikai and Frank Goodnow. China File, December 30, 2015. http://www.chinafile.com/reporting-opinion/viewpoint/perils-advising-empire. 
Lieberthal, Kenneth. 2010. Reflections on the China field in political science. In Contemporary Chinese politics: New sources, methods, and field strategies, ed. Allen Carlson, Mary E. Gallagher, Kenneth Lieberthal, and Melanie Manion. New York: Cambridge University Press of America.

Liang, Ying. 2012. New cross-disciplines in the contemporary Chinese political studies: Reality and prospect of development-a case study of seven new developing cross-disciplines in China. Jiangsu Social Sciences 6: 142-148.

Liu, Han and Yang, Long. 1999. 50 nian lai de Zhongguo zhengzhixue [China's political science of the past 50 years]. Zhengzhixue yanjiu 49(40): 1-13.

Noakes, Stpehen. 2014. The role of political science in China: Intellectuals and authoritarian resilience. Political Science Quarterly 129(2): 239-260.

Palm, Daniel C. 2012. Chinese encounters with foreign ideas in the self-strengthening movement (1861-1895). A paper prepared for the American Association of Chinese Studies Conference, October 13-14, 2012, Atlanta, Georgia.

Peters, Guy, Jon Pierre, and Gerry Stoker. 2010. The relevance of political science. In Theory and methods in political science, 3rd ed, ed. David Marsh, and Gerry Stoker. Basingstoke: Palgrave Macmillan.

Petracca, Mark P. 1990. Political science in China: A new state of siege. PS Political Science and Politics 23(June): 253-257.

Qin, Yaqing. 2011. Development of international relations theory in China: Progress through debates. International Relations of the Asia-Pacific 11(2): 231-257.

Rogowski, Ronald. 2013. Shooting (or ignoring) the messenger. Political Studies Review 11: 216-221.

Song, Yingfa. 2015. Research methods in Chinese political science: Status Quo and future trends. In: IPSA conference on methods in political science: A rainbow of challenges. University of Antwerp, September 16-18, 2015, Antwerp, Belgium.

Sun, Hongyun. 2005. The Unfolding of China's modern political science: The early development of the political science Department of Tsinghua University. Beijing: The SDX Joint Publishing Company.

Taylor, Jon R. 2009. Choices for Chinese political science: Methodological positivism or methodological pluralism? Journal of Chinese Political Science 14(December): 357-367.

Taylor, Jon R. 2011. Let one hundred flowers bloom, let one hundred thoughts contend: Political science with Chinese characteristics. Journal of Chinese Political Science 16(June): 323-333.

Trent, John E. 2011. Should political science be more relevant? An empirical and critical analysis of the discipline. European Political Science 10: 191-209.

Tsinghua School of Social Sciences. 2015. Academic symposium of "China's politics in the 21st century" held in Tsinghua University.

Wang, Shaoguang. 2011. Thirty years of political science in China: From learning from the west to indigenization. Social Sciences in China 33(August): 23-37.

Wang, Shaoguang. 2013. To 'fall in line' or to 'grab': Thoughts on the indigenization of political science. In Political science and Chinese political studies: The state of the field, ed. Sujian Guo. New York: Springer.

Wangling, Min. 2007. "Minguo zhengzhi sue de si qi fazhan" ["Four Stages of Political Science during the Period of Republic of China"]. Huadong Shifan Daxue Xuebao (Zhaxue Shehui Kexue Ban) 39(2): 26-33.

Wood, Matthew. 2014. Bridging the relevance gap in political science. Politics 34(3): 275-286.

Wu, Guoguang. 2013. Politics against science: Reflections on the study of political politics in contemporary China. In Political science and Chinese political studies: The state of the field, ed. Sujian Guo. New York: Springer.

Yu, Keping. 2009. The study of political science and public administration in China. In: Democracy is a good thing: Essays on Politics, Society, and Culture in Contemporary China. Washington, DC: Brookings Institution Press.

Zhao, Baoxu. 1984. The revival of political science in China. PS Political Science and Politics 17(Autumn): 745-757.

Zweig, David. 2002. Internationalizing China: Domestic interests and global linkages. Ithaca: Cornell University Press. 
Jon R. Taylor is a Professor of Political Science at the University of St. Thomas, Chair of the Department of Political Science, and Director of the Master of Public Policy and Administration Program. He holds a Ph.D. in Political Science from the University of Oklahoma. His scholarly specializations are in Chinese public administration and policy, Chinese politics, Public administration ethics, and urbanization. 